\title{
Foreign language skills and employment status of European natives: evidence from Germany, Italy and Spain
}

\section{Michele Gazzola $^{1}$ (1) $\cdot$ Daniele Mazzacani ${ }^{2}$ (i)}

Published online: 21 September 2019

(c) The Author(s) 2019

\begin{abstract}
This article examines the relationship between foreign language skills and the employment status of natives in Germany, Italy and Spain. Using a probit model and data from Eurostat's Adult Education Survey 2011, this article studies the conditional correlation between knowledge of English and French as foreign languages, and the probability of being employed, comparatively, for men and women. The results reveal that skills in English increase the probability of being employed for men in the three countries, respectively, by 3.4, 4.3 and 5.2\%. Knowledge of English increases the probability of being employed for women in Germany and Italyrespectively, by 5.6 and 5.7\% - but not in Spain. The results also show that very good skills are associated with a higher probability of being employed than sufficient or good skills. The conditional correlation between knowledge of English and employment status for men is larger in countries where skills in this language are less common among the population, and where the unemployment rate is higher. This is consistent with the fundamental economic concept of scarcity. Estimates for French are not statistically significant.
\end{abstract}

Keywords Foreign language skills $\cdot$ Employment status $\cdot$ Employability $\cdot$ Language policy $\cdot$ Germany $\cdot$ Italy $\cdot$ Spain $\cdot$ European labour market $\cdot$ Human capital

JEL Classification I26 $\cdot \mathrm{J} 21 \cdot \mathrm{J} 24 \cdot \mathrm{Z} 13$

Michele Gazzola

m.gazzola@ulster.ac.uk

Daniele Mazzacani

daniele.mazzacani@economics.unibz.it

1 Faculty of Arts Humanities and Social Sciences, School of Applied Social and Policy Sciences, Ulster University, Shore Road, Jordanstown BT37 0QB, UK

2 Faculty of Economics and Management, Free University of Bozen-Bolzano, Piazza Università 1, Bolzano-Bozen 39100, Italy 


\section{Introduction}

This article addresses the relationship between foreign language skills and the employment status of native Europeans, and it provides new, empirical results on this relationship. During the last decade, the official EU discourse about foreign language learning and teaching has gradually changed. While learning foreign languages was traditionally associated with an openness to other European cultures, nowadays the EU discourse on multilingualism emphasises the importance of foreign language skills for economic growth, competitiveness, mobility of labour, and employability. A working paper published in 2012 by the European Commission illustrates this trend:

Europe's vision for 2020 is to become a smart, sustainable and inclusive economy. Therefore, improving the outcomes of education and training and investing in skills in general-and language skills in particular-are important prerequisites to achieve the EU goal of increasing growth, creating jobs, promoting employability and increasing competitiveness. The ambition is to achieve better functioning of EU labour markets, to provide the right skills for the right jobs and to improve the quality of work and working conditions. In this context, foreign language proficiency is one of the main determinants of learning and professional mobility, as well as of domestic and international employability. Poor language skills thus constitute a major obstacle to free movement of workers and to the international competitiveness of EU enterprises. [...] it is clear, however, that the benefits of improved language learning go well beyond the immediate economic advantages, encompassing a range of cultural, cognitive, social, civic, academic and security aspects (European Commission 2012: 4, italics added).

The EU, therefore, does not intend to neglect the cultural or cognitive aspects of language learning; quite simply the scope of EU language policy has been broadened. This change has gradually emerged since 2000 in different important policy documents such as the Action Plan 2004-2006 (European Commission 2003), the communication A new strategic framework for multilingualism (European Commission 2005), and the communication Multilingualism: An asset for Europe and a shared commitment (European Commission 2008). The change in the official discourse on multilingualism must be linked to two factors. The first one is strategic. Language policy, and in particular foreign language teaching, is viewed as an element contributing to the achievement of the general socio-economic objectives of the EU defined in the Lisbon Agenda 2000-2010 (Krzyżanowski and Wodak 2011), and to the achievement of the goals of the Europe 2020 Agenda. ${ }^{1}$ The second factor is reactive. After the outbreak of the financial crisis in 2008 and the European sovereign

\footnotetext{
1 The Lisbon Agenda was a plan developed by the European Commission, aimed at making the EU "the most competitive and dynamic knowledge-based economy in the world, capable of sustainable economic growth with more and better jobs and greater social cohesion by 2010". It was followed by Europe 2020, a 10-year strategy aiming at "smart, sustainable, inclusive growth" with greater coordination of national and European policy.
} 
debt crisis in 2011, the unemployment rate in the EU increased and reached a peak in 2013. It was 7\% in 2008 (6.6\% for men, $7.5 \%$ for women), $10.9 \%$ in 2013 (10.8 and $10.9 \%$ for men and women, respectively), and then it decreased to $6.8 \%$ in 2018 (6.6\% for men, 7.1\% for women). Large differences among countries exist. For example, in 2013, the unemployment rate was 5.2\% in Germany, $12.1 \%$ in Italy, and $26.1 \%$ in Spain. The youth unemployment rate is much higher than the average unemployment rate. The economic crisis severely hit the young. In 2008, the youth unemployment rate started to grow quickly peaking in $23.8 \%$ at the beginning of 2013, before receding to $15.2 \%$ in 2018 .

Against this backdrop, foreign language skills are viewed as a component of Europeans' human capital that can generate benefits in the domestic labour market, such as higher wages, or better employment opportunities. Reducing unemployment also matters for equity, because employment can be viewed as a dimension of social inclusion. Although the European Commission, as shown above, asserts that "foreign language proficiency is one of the main determinants of learning and professional mobility, as well as of domestic and international employability", few scientific papers address the question of the relationship between foreign language skills and employment, let alone employability. This article contributes to bridging this gap. To understand better why we focus on employment, a terminological note is needed. While the unemployment rate is clearly defined, the definition of what employability means is far from clear and many definitions coexist (McQuaid and Lindsay 2005). The official definition used by the European Commission is the: "ability to gain initial employment, to maintain employment, and to be able to move around within the labour market", but it is not clear which indicators should be used to measure it. For this reason, the empirical studies available, as well as this article, concentrate on one dimension of employability only, that is, the employment status at a given moment.

The rest of this article is organised as follows: Section 2 discusses the relevant literature. Section 3 presents the database and our estimation strategy. Section 4 provides an overview of the linguistic skills of native-born citizens (henceforth "natives") in Germany, Italy and Spain, and it illustrates the characteristics of the sample. Section 5 presents the results of two econometric models. Section 6 provides a critical discussion of the results and an overall conclusion.

\section{Literature review}

The majority of existing quantitative studies on the effects of language skills on labour market outcomes estimate earning differentials accruing to multilingual people, and for this reason they will not be discussed here (for recent overviews, see Gazzola et al. 2016; Isphording 2015; Zhang and Grenier 2013; Chiswick and Miller 2007).

The papers dealing with the effect of language skills on employment can be divided into two groups. The first group collects contributions that study the relationship between the employment opportunities of immigrants and the acquisition of good skills in the official language of the host country (Budría et al. 2019; Zorlu 
and Hartog 2018; Yao and van Ours 2015; Isphording and Otten 2014; Chiswick and Miller 2015; Maxwell 2010; Aldashev et al. 2009; Dustmann and Fabbri 2003; Leslie and Lindley 2001). Some authors examine the effects of acquiring proficiency in a minority language that is co-official in a given region or country, such as Catalan for people who move to Catalonia (Rendon 2007), or English in South Africa (Cornwell and Inder 2008).

The second group of papers focuses on foreign (or second) language skills and the employment status of the resident population, and is more relevant for the purposes of this article. The earliest study is by Vaillancourt (1988) who uses Canadian census data and a probit model to estimate the net impact of language skills on being employed or not in 1980 in Québec. The results show that bilingualism in English and French increases the odds of being employed for women (men) by $6.5 \%(1.8 \%)$ for anglophones, 9.5\% (3\%) for francophones and 10.5\% (3.9\%) for allophones. Using an ad hoc data set in Switzerland, Grin et al. (2009, 2010) study the relationship between employment and skills in English, French, and German as second languages. They show that, if the average wage increases by $5 \%$, the demand for monolingual workers decreases by $8.7 \%$, but the demand for multilingual workers decreases only by $3.7 \%$. Duncan and Mavisakalyan (2015) use the Data Initiative Survey to show that in some former Republics of the Soviet Union (i.e. Armenia, Azerbaijan, and Georgia) skills in Russian language increase, ceteris paribus, the probability of employment by about $6 \%$ for men and $9 \%$ for women. Lindemann and Kogan (2013) employ data from the Estonian TIES survey and the Youth Transition Survey in Ukraine to study the role of language competency for labour market entry of the young in Estonia and Ukraine. The results show that in Estonia knowledge of Estonian is important to the Russian-speaking minority in order to gain faster access to employment, whereas this in not the case for skills in Ukrainian in Ukraine.

There are four cross-national studies examining the relationship between employment and foreign language skills in the European Union. The first two studies use data from vacancy notices. Beadle et al. (2015) reports the results of 845 interviews with employers and employer organisations on the use and utility of foreign languages, the review of 3632 online vacancy notices, and interviews with 522 employers. The authors show that a significant percentage of employers require an advanced level of foreign language skills. Fabo et al. (2017) investigate the economic importance of foreign language skills in the Visegrad group of countries (i.e. Czech Republic, Hungary, Poland, and Slovakia) using data obtained from key online vacancy boards and from the Wage Indicator survey, a continuous, voluntary, web-based survey of wages and working conditions. The results indicate that in the Visegrad region skills in English, and to a lesser extent German, are in high demand. The third study (Donado 2017) investigates the conditional impact of knowing foreign languages on the likelihood of unemployment in different European countries using a repeated cross-section of more than 124,000 native residents (immigrants are excluded) aged 15 and over from 31 European countries. The data come from various waves of Eurostat's Eurobarometer surveys covering the period between 1990 and 2012. Using a linear probability model, the author shows that knowing a foreign language reduces the probability of being unemployed by at least $3.4 \%$, and this percentage is higher for women than men. This conditional impact is stronger for English (4.6\%), followed 
by German (2.1\%), Italian (2\%), and French (1.9\%), while the results for Spanish are not statistically significant. Substantial differences exist between the countries (Donado 2017: 275). The results obtained with an OLS regression in which linguistic distance is used as an instrumental variable (IV) show that the impact of foreign language skills on unemployment is significant only for English and German. Estimates of such an impact are higher than those obtained with the linear probability model. However, differences in the level of language skills are not examined.

The fourth study (Araújo et al. 2015) employs logistic regressions and data from Eurostat's Adult Education Survey (AES) 2011 to explore the relationship between knowledge of one or more foreign languages and the employment status of adult Europeans. The study reports a positive relationship between employment and knowledge of English in Germany, Greece, Italy, Latvia, Lithuania, Luxembourg, Malta, the Netherlands, Portugal, and Slovenia. In Cyprus, Spain, and Finland proficiency in English (that is, very good language skills) is associated with a higher probability of being employed. People knowing at least some French are more likely to be employed in Malta, those who know German are more likely to be employed in Denmark, while Russian is associated with a higher probability of being employed in Bulgaria, Latvia, Lithuania, and Poland. However, this paper shows three shortcomings. First, it reports the coefficients of the models used, but it does not estimate the related marginal effects. While this allows the authors to assess the sign of the existing relationships, no conclusion can be drawn about the magnitude of such relationships. Second, gender differences in the language-employment relationship are not explored. Finally, the relationship between employment and the level of language skills is incomplete, because it is examined only for English and only for a very good level of skills.

This article aims to deepen the research of Araújo et al. (2015). ${ }^{2}$ Using probit models with detailed specifications, we provide estimates of the marginal effects of foreign language skills on the probability of being employed, for men and women separately, and for different levels of language skills. We focus on the domestic labour market of three EU countries - Germany, Italy and Spain-and on their most commonly spoken foreign languages, namely English and French. We select these countries for a number of reasons which are explained in Sect. 4. The available data do not offer sources of exogenous variation in language proficiency, which would allow us to identify those effects entirely unrelated to unobserved individual characteristics. Therefore, similar to other studies in language economics (e.g. Di Paolo and Tansel 2019; Yao and van Ours 2019), this article focuses on existing conditional correlations between foreign languages and employment, rather than on the causal effect of the former on the latter. In both our models, however, we control for the main socio-economic determinants of employment in more detail than in Araújo et al. (2015), thus reducing the possibility of bias. Although we cannot draw conclusions of a causal nature, we consider that the estimates obtained are reliable from a qualitative point of view, and that they represent a useful contribution to future analyses.

\footnotetext{
2 Our study is based on data from Eurostat Adult Education Survey (AES) 2011. The responsibility for all conclusions drawn from the data lies entirely with the authors.
} 


\section{Database and estimation strategy}

This article uses data from the second edition of the AES, collected between 2011 and 2012 and published at the end of 2013. The survey covers the current $28 \mathrm{EU}$ Member States, excluding Croatia, and some of the countries belonging to the European Free Trade Association (EFTA), such as Norway and Switzerland. The AES has a rich linguistic section recording data on the native language and up to seven nonnative language(s) of European residents aged 25-64. The data set covers 49 different languages. Furthermore, it provides data on respondents' level of proficiency in the two best-known non-native languages. More specifically, respondents are asked to self-assess their language skills using the following descriptors of competence:

- Sufficient "I can understand and use the most common everyday expressions. I use the language in relation to familiar things and situations".

- Good "I can understand the essentials of clear language and produce simple texts. I can describe experiences and events and communicate fairly fluently".

- Proficient "I can understand a wide range of demanding texts and use the language flexibly. I master the language almost completely".

A possible criticism concerns the reliability of subjectively self-assessed language skills. It is not possible to assess the accuracy of the AES data in this respect. However, research comparing self-assessment with teachers' evaluations has shown that the former is more accurate if learners "respond to 'can do' statements that define concrete language use experiences that are familiar to the learners than if they are asked to use a proficiency scale with more abstract definitions of language skills" (Ross 1998, quoted in Luoma 2013: 4).

The survey also contains quite comprehensive information on the socio-economic status of the respondents, including their age, gender, family status (i.e. marital and parental status), level of education completed, and current labour status. Unfortunately, income data at the individual level are not available in the AES. Therefore, it is not possible to carry out an analysis of the relationship between languages skills and earning differentials. ${ }^{3}$

To study the effect of individual language proficiency on the employment status, we model the probability of being employed with a binary probit equation. In doing so, we interpret the explanatory variables as being able to influence an unobserved propensity for employment, for which we can only observe one binary output, i.e. employed or non-employed. By choosing the probit model instead of the logit model, as in Araújo et al. (2015), we are assuming this propensity to have standard normal distributed error terms. ${ }^{4}$ In the equation, we include survey variables that can influence the unobserved propensity for employment. Furthermore, taking advantage of

\footnotetext{
3 The income variable is defined as the decile of net monthly income of the household, including social benefits.

4 Probit models have already been used in the study of the relationship between language and employability, for instance in the case of Catalan in Catalonia (Rendon 2007) and Québec (Vaillancourt 1988).
} 
the detailed data available, we specify the linguistic part of the equation in two different ways. In the first specification, named Model 1, we treat language skills in a given language as a single dichotomous variable. In other words, we estimate the relationship between having at least some knowledge of a given foreign language and the probability of being employed, all other things being equal. In the second specification, Model 2, we introduce heterogeneity regarding language ability using the descriptors presented above. The first specification investigates whether knowledge of foreign languages, in general, is positively, conditionally correlated with the employment status of native individuals. The second specification deepens the analysis, exploring how specific levels of language proficiency relate to the employment status. Since foreign language skills are just one of the several variables that may impact on employment, we complete the analysis defining a set of socio-economic control variables, which remains unchanged in both models. Following the common practice in labour economics research, we control for age, experience, educational background, family status and regional effects. ${ }^{5}$ In the two models the conditional probability of employment is defined as follows:

Model 1:

$$
\operatorname{Pr}\left[y_{i}=1 \mid X_{i}, F L A_{i}, F L B_{i}\right]=\Phi\left(\beta_{0}+\beta^{\prime} X_{i}+\gamma_{1} F L A_{i}+\gamma_{2} F L B_{i}+\varepsilon_{i}\right)
$$

Model 2:

$$
\operatorname{Pr}\left[y_{i}=1 \mid X_{i}, S F L A_{i}, S F L B_{i}\right]=\Phi\left(\beta_{0}+\beta^{\prime} X_{i}+\sum_{l=0}^{3} \theta_{1 l} S F L A_{i}+\sum_{l=0}^{3} \theta_{2 l} S F L B_{i}+\varepsilon_{i}\right)
$$

In both equations, $y_{i}=\{0,1\}$ is a dummy variable for the employment status, equal to one if individual $i$ is employed and to zero otherwise. Since we are using probit models, $\Phi(\cdot)$ is the cumulative distribution function for the standard normal distribution. In both models, we consider two different foreign languages, here labelled language $A$ and language $B$, and we create specific linguistic variables for each of them. Each of these variables is constructed by merging the original data on the two best-known foreign languages reported by respondents. Hence, the variable for language $A$ (respectively, language $B$ ) records whether the respondent declares an ability to speak language $A$ (language $B$ ) as a foreign language in general, no matter if it is his or her first or second best-known foreign language. In our analysis, proficiency in more than two foreign languages cannot be considered because the AES reports data on the level of skills just in the first and second foreign language. The specifications of Model 1 and Model 2 differ in how language skills are examined. In Eq. 1, $F L A_{i}$ and $F L B_{i}$ are two dummy variables representing the two foreign languages most frequently known by individual $i$ in a given country, at any level of competence. Depending on one's language skills, an individual may not know any foreign language (both dummies equal to zero), only one language $\left(F L A_{i}\right.$ or $F L B_{i}$ equal to one) or two languages (both $F L A_{i}$ and $F L B_{i}$ equal to one) at a sufficient,

\footnotetext{
5 See e.g. Aldashev et al. (2009), Leslie and Lindley (2001), Rendon (2007) for similar specifications in comparable research questions.
} 
good or very good level. Model 2 does not aggregate the levels of competence in a single dummy for each language, but it analyses them separately. For this purpose, we define four different dummy variables for language $A\left(S F L A_{i}\right)$ and language $B$ $\left(S F L B_{i}\right)$, and each dummy corresponds to a level of skill, including zero. Thus, in the Eq. 2, $\theta_{1 l}$ (as well as $\theta_{2 l}$ ) captures the effect on employment of speaking language $A$ (respectively, language $B$ ) at a skill level $l$, where $l=1$ for sufficient, 2 for good and 3 for proficient. For each of the two languages, the reference level corresponds to respondents who declare no knowledge of the language considered (that is $l=0$ for $S F L A_{i}$ and $S F L B_{i}$, respectively). As for the first model, also in the second equation, an individual may report knowing zero, one or two foreign languages.

The vector of variables $X_{i}$ is also common to the two models, and it controls for six dimensions, namely:

- Age: respondent's age, from 25 to 64.

- $A g e^{2}$ we control for non-linear age effects by including the square of age. Note that we cannot explicitly control for work experience, since this variable cannot be constructed from the data. ${ }^{6}$

- Married dummy variable indicating whether the respondent is married, including registered partnerships. Not being married includes widowed and not remarried, legally separated and not remarried, divorced, and single.

- Child dummy variable indicating whether the respondent has at least one child aged less than 25 living at home.

- Degree of urbanisation included with three alternative dummy variables indicating whether the respondent lives in a densely ( $u r b 1$ ), intermediate (urb2) or thinly populated area (urb3). The reference category is the densely populated area ( $u r b 1)$. We control for the degree of urbanisation as a result of a lack of information on the geographical region in which a respondent lives. This is the only control available as a proxy for regional fixed effects. ${ }^{7}$

- ISCED 1, ISCED 2, ISCED 3, ISCED 4, and ISCED 5 dummy variables accounting for the highest level of education successfully completed by the respondent, according to ISCED classification. ${ }^{8}$ Education dummies cover primary/pre-primary (ISCED 1), lower secondary (ISCED 2), upper secondary (ISCED 3), postsecondary non-tertiary (ISCED 4) and tertiary-and-above (ISCED 5) levels of

\footnotetext{
${ }^{6}$ Work experience is usually approximated by the age minus years of schooling minus six years of infancy. Note, however, that this measure would assume that all individuals work without breaks years after infancy and schooling. Since we want to estimate the relationship between individuals' language skills and their employment status, this approximation is likely to be harmful to our specification.

7 Information on the geographical regions would be a valuable source of variation in employment status across regions but it has been anonymised in the final version of the AES. See Sect. 6 for a discussion.

8 The AES reports completed education in ISCED levels. ISCED stands for "International Standard Classification of Education", a system developed by UNESCO to facilitate comparisons between the education systems of different countries. Omitting achieved education would introduce a relevant bias in our analysis, overestimating the impact of language skills on the explained variable.
} 
education, respectively. The reference category for both models is a primary or lower level of education (ISCED 1). ${ }^{9}$

\section{Overview, descriptive statistics and sample characteristics}

We focus on the native individuals in Germany, Italy and Spain for several reasons. First, these countries are among the most populated in Europe, and this is reflected in the size of the national statistical sample. Second, in the three countries the two most commonly spoken foreign languages are the same (e.g. English and French), and such languages are known by a significant percentage of the population. Third, they have only one official language at national level-local languages in Spain are co-official only in their respective regionsand none of their national or local languages coincides with English or French. Fourth, they give us the opportunity to investigate quite different contexts in terms of language knowledge and employment: in 2011, the employment rate was higher than the EU average in Germany, close to the average in Italy and below average in Spain. ${ }^{10}$ Finally, restricting the analysis to a few countries allows the study to be enriched with specific comments on their situations.

We focus on natives, which we define as the respondents who are both born in a given country and citizens of that country. This allows us to identify the actual natives correclty, as confirmed in Table 1 by the fact that the percentage of respondents declaring they speak German as a foreign language in Germany or Italian in Italy is close to zero. In Spain the fraction of natives who report Spanish as a foreign language mirrors the sociolinguistic situation of the country. ${ }^{11}$ The article, therefore, deliberately excludes immigrants from the analysis, i.e. both EU-citizens abroad and people from third countries. First, immigrants' native language could correspond to a foreign language for natives (as English for immigrants from a former British colony), while at the same time immigrants may have limited competence in the official language of the host country. Second, the literature in language economics emphasises that immigrants can suffer from discrimination in the labour market of the host country for reasons that are independent of their skills in foreign languages. This can be the result of negative attitudes on the part of the native population towards their ethnic group, to their limited knowledge of the local dominant language (sometimes

\footnotetext{
9 The models specified by Araújo et al. (2015) control neither for work experience nor for the presence of children. Moreover, both variables capturing age and education effects are grouped into less specific macro-classes, and the degreee of urbanisation is not taken into account.

${ }^{10}$ Different factors may contribute to explaining these differences. Among others, let us mention the higher decentralisation in the wage setting in Germany, which considerably improved the competitiveness of the German economy in the last decade (Dustman et al. 2014), as well as the importance of informal networks, such as family and friends, in the labour market in Italy and Spain (Naticchioni et al. 2010; Jaumotte 2011).

11 In some autonomous regions there may be an opposition between Spanish national identity on the one hand and regional identity on the other. Of the (few) Spaniards who claim to speak Spanish as a foreign language in the sample, six out of ten are native speakers of Catalan, followed by native speakers of Basque and Galician.
} 
Table 1 Foreign languages known by natives aged 25-64 in Germany, Italy and Spain

\begin{tabular}{lccc}
\hline & Germany & Italy & Spain \\
\hline Language & & & \\
English & 72.0 & 46.2 & 31.2 \\
French & 19.8 & 23.2 & 13.0 \\
German & 0.6 & 4.9 & 2.0 \\
Spanish & 6.9 & 4.4 & 5.6 \\
Italian & 4.7 & 0.4 & 2.1 \\
Russian & 9.0 & 0.2 & 0.1 \\
\hline
\end{tabular}

Results in percentage

Individuals may report knowledge of more than one language up to seven languages. The results have been weighted so as to refer to the total population of each country

even simply to their accent) or a combination of the two factors (for a discussion see Chiswick and Miller 2007; Grin et al. 2010). As a consequence, the analyses required for native and non-native individuals are conceptually different, and, therefore, only the first group is considered here.

Table 1 shows the most commonly known foreign languages in the three countries studied. This table includes data from the first to the seventh foreign language known by respondents (if any). ${ }^{12}$ English is more widely known in Germany than in Italy or Spain. Knowledge of French is more common in Italy than in Germany or Spain. Other languages are spoken by a lower (albeit not negligible) percentage of the population.

Table 2 reports respondents' self-reported levels of skill in English and French. Recall that variables on the level of skills are available only for the first and second foreign languages known by respondents, and, therefore, the percentages in Tables 1 and 2 can slightly differ. Data show that just a minority of individuals report being proficient in these two languages, a more significant part master them at a good level, while the majority reports knowing them at a sufficient level. Hence, contrary to what is commonly believed, fluency in foreign languages is not a basic skill of Europeans yet.

In building the outcome variable, and in a similar way to what was done by Araújo et al. (2015), we identify as employed $\left(y_{i}=1\right)$ individuals working either full-time or part-time. On the other hand, we consider as non-employed $\left(y_{i}=0\right)$ those who are not working, after excluding students, permanently disabled

\footnotetext{
12 Knowledge of more than two foreign languages is, however, uncommon: around $95 \%$ of the individuals in the three countries speak between zero and two foreign languages, with the two most spoken languages always being English and French. Adding the knowledge of a third language would increase this share from 95 to $99 \%$ of the population. The number of respondents for the third foreign language, however, is too small and does not allow for further investigation.
} 
Table 2 Level of skills in English and French of natives aged 25-64 in Germany, Italy and Spain

\begin{tabular}{lccc}
\hline & Germany & Italy & Spain \\
\hline English & & & \\
No knowledge & 28.3 & 54.1 & 69.5 \\
Sufficient & 36.2 & 29.7 & 12.1 \\
Good & 24.4 & 11.8 & 13.1 \\
Proficient & 11.1 & 4.4 & 5.3 \\
French & & & \\
No knowledge & 83.6 & 77.6 & 88.1 \\
Sufficient & 12.4 & 17.2 & 5.9 \\
Good & 2.9 & 3.8 & 4.4 \\
Proficient & 1.1 & 1.4 & 1.6 \\
\hline
\end{tabular}

Results in percentage

Only the first and the second best-known foreign languages are considered. The results have been weighted so as to refer to the total population of each country

individuals and respondents on compulsory military service. ${ }^{13}$ To take gender differences into account we divide the sample between men and women.

While Tables 1 and 2 refer to the whole population, Tables 3 and 4 present the descriptive statistics of the sample, respectively, for men and women. Both tables report the share of respondents declaring a knowledge of English and French in general (this piece of information is used in Model 1), as well as the level of language skills in the two languages (these are examined in Model 2). Table 3 points out high levels of employment for men in all three countries. As expected, differences exist between countries: while Germany has the highest level of male employment (82\%), Spain shows the worst situation, with 10 percentage point less (72\%), and Italy stands between them, but it is closer to Germany (78\%). The male sample maintains the characteristics of the whole population in terms of language knowledge and proficiency levels. English is widespread among German men (71\%), while fewer Italians (49\%) and fewer Spaniards (29\%) show some knowledge of it. French is better known in Italy than in the other two countries. Reported levels of proficiency are similar to those of the whole population for both languages.

Table 4 reports data for women. Differences in the percentage of employed people across countries are similar to those reported in Table 3 for men. One can note, however, that there is a substantial gender gap, as women are less likely to be employed than men. Such a gap is smaller in Germany and Spain (14 and 16 percentage points, respectively) than in Italy ( 21 percentage points). In the three

\footnotetext{
13 The non-employed category includes individuals who are (1) unemployed (2) in retirement, early retirement or have given up business; (3) fulfilling domestic tasks and (4) other category of inactive person. This choice is to avoid removing conditions that are likely to depend on individual choices or gender. In particular, category (3) is likely to be relevant when exploring the relationship between languages and employment for women: individuals doing domestic work represent almost $19 \%$ of the female sample (and only $0.25 \%$ of the male sample).
} 
Table 3 Descriptive statistics, Model 1 and 2

\begin{tabular}{|c|c|c|c|}
\hline Variable & Germany & Italy & Spain \\
\hline Employment & .82 & .78 & .72 \\
\hline \multirow[t]{2}{*}{ Age } & 46.72 & 46.36 & 44.24 \\
\hline & $(10.80)$ & $(10.56)$ & $(10.86)$ \\
\hline Married & .61 & .67 & .59 \\
\hline Children & .33 & .50 & .48 \\
\hline \multicolumn{4}{|c|}{ Degree of urbanization } \\
\hline Densely populated & .48 & .45 & .41 \\
\hline Intermediate & .36 & .41 & .25 \\
\hline Thinly populated & .16 & .14 & .33 \\
\hline \multicolumn{4}{|l|}{ Education } \\
\hline ISCED 1 & .01 & .06 & .02 \\
\hline ISCED 2 & .05 & .33 & .49 \\
\hline ISCED 3 & .49 & .39 & .21 \\
\hline ISCED 4 & .09 & .05 & 0 \\
\hline ISCED 5 & .36 & .17 & .29 \\
\hline \multicolumn{4}{|c|}{ Language knowledge (general) } \\
\hline English & .71 & .49 & .29 \\
\hline French & .15 & .20 & .11 \\
\hline \multicolumn{4}{|c|}{ Language knowledge (level) } \\
\hline \multicolumn{4}{|c|}{ English } \\
\hline No knowledge & .29 & .51 & .71 \\
\hline Sufficient & .33 & .30 & .12 \\
\hline Good & .26 & .14 & .12 \\
\hline Proficient & .12 & .05 & .05 \\
\hline \multicolumn{4}{|l|}{ French } \\
\hline No knowledge & .85 & .80 & .89 \\
\hline Sufficient & .12 & .15 & .06 \\
\hline Good & .02 & .04 & .04 \\
\hline Proficient & .01 & .01 & .02 \\
\hline Obs. & 2451 & 3783 & 5226 \\
\hline
\end{tabular}

Men aged 25-64

Results in share. Standard deviation, reported only for continuous variables, in brackets

countries, women's skills in English are similar to those of men, both in general and in terms of proficiency levels. Conversely, women tend to know French better than men. Looking at the main socio-demographic variables, the male and female samples show similar proportions of married individuals in the countries examined. The percentage of women and men in the sample who have children is similar in Italy and Spain, while in Germany women are more likely to have children than men. We do not observe major gender differences in the degree of urbanization, while at country level Spain shows a higher concentration in thinly-populated areas. Finally, 
Table 4 Descriptive statistics, Models 1 and 2

\begin{tabular}{|c|c|c|c|}
\hline Variable & Germany & Italy & Spain \\
\hline Employment & .68 & .57 & .56 \\
\hline \multirow[t]{2}{*}{ Age } & 46.11 & 46.24 & 44.90 \\
\hline & $(10.49)$ & $(10.54)$ & $(10.85)$ \\
\hline Married & .63 & .68 & 63 \\
\hline Children & .42 & .51 & .53 \\
\hline \multicolumn{4}{|c|}{ Degree of urbanization } \\
\hline Densely populated & .45 & .46 & .45 \\
\hline Intermediate & .39 & .41 & .26 \\
\hline Thinly populated & .16 & .13 & .29 \\
\hline \multicolumn{4}{|l|}{ Education } \\
\hline ISCED 1 & .02 & .10 & .02 \\
\hline ISCED 2 & .08 & .27 & .43 \\
\hline ISCED 3 & .50 & .36 & .22 \\
\hline ISCED 4 & .08 & .05 & 0 \\
\hline ISCED 5 & .32 & .22 & .33 \\
\hline \multicolumn{4}{|c|}{ Language knowledge (general) } \\
\hline English & .70 & .49 & .30 \\
\hline French & .19 & .29 & .13 \\
\hline \multicolumn{4}{|c|}{ Language knowledge (level) } \\
\hline \multicolumn{4}{|l|}{ English } \\
\hline No knowledge & .30 & .51 & .70 \\
\hline Sufficient & .36 & .33 & .13 \\
\hline Good & .24 & .11 & .12 \\
\hline Proficient & .10 & .05 & .04 \\
\hline \multicolumn{4}{|l|}{ French } \\
\hline No knowledge & .81 & .71 & .87 \\
\hline Sufficient & .14 & .22 & .07 \\
\hline Good & .03 & .05 & .05 \\
\hline Proficient & .02 & .02 & .01 \\
\hline Obs. & 2710 & 3995 & 5694 \\
\hline
\end{tabular}

Women aged 25-64

Results in share. Standard deviation, reported only for continuous variables, in brackets

in Italy and Spain, women tend to be more educated than men, whereas the opposite is true in Germany, albeit to a lesser extent.

\section{Estimates}

From Tables 5, 6, 7, and 8, we present the results of the estimates of Models 1 and 2. To assess both the sign and the magnitude of the conditional correlation between variables, we report in the table the marginal effects rather than the coefficients of 
Table 5 Probit regression

\begin{tabular}{|c|c|c|c|}
\hline Variables & $\begin{array}{l}\text { (1) } \\
\text { Germany }\end{array}$ & $\begin{array}{l}(2) \\
\text { Italy }\end{array}$ & $\begin{array}{l}\text { (3) } \\
\text { Spain }\end{array}$ \\
\hline Age & $\begin{array}{l}0.049 * * * \\
(0.006)\end{array}$ & $\begin{array}{l}0.097 * * * \\
(0.006)\end{array}$ & $\begin{array}{l}0.049 * * * \\
(0.005)\end{array}$ \\
\hline $\mathrm{Age}^{2}$ & $\begin{array}{l}-0.001 * * * \\
(0.000)\end{array}$ & $\begin{array}{l}-0.001^{* * *} \\
(0.000)\end{array}$ & $\begin{array}{l}-0.001 * * * \\
(0.000)\end{array}$ \\
\hline Married & $\begin{array}{l}0.096 * * * \\
(0.017)\end{array}$ & $\begin{array}{l}0.065 * * * \\
(0.017)\end{array}$ & $\begin{array}{l}0.101 * * * \\
(0.016)\end{array}$ \\
\hline Child & $\begin{array}{l}0.033 \\
(0.020)\end{array}$ & $\begin{array}{l}0.037 * * \\
(0.015)\end{array}$ & $\begin{array}{l}0.062 * * * \\
(0.015)\end{array}$ \\
\hline Intermediate area & $\begin{array}{l}-0.002 \\
(0.0162)\end{array}$ & $\begin{array}{l}0.003 \\
(0.0143)\end{array}$ & $\begin{array}{l}-0.008 \\
(0.0163)\end{array}$ \\
\hline Thinly-populated area & $\begin{array}{l}0.013 \\
(0.019)\end{array}$ & $\begin{array}{l}-0.015 \\
(0.022)\end{array}$ & $\begin{array}{l}0.028 * \\
(0.015)\end{array}$ \\
\hline ISCED 2 & $\begin{array}{l}0.217 * * \\
(0.106)\end{array}$ & $\begin{array}{l}0.109 * * \\
(0.042)\end{array}$ & $\begin{array}{l}0.163 * * * \\
(0.062)\end{array}$ \\
\hline ISCED 3 & $\begin{array}{l}0.319 * * * \\
(0.097)\end{array}$ & $\begin{array}{l}0.229 * * * \\
(0.043)\end{array}$ & $\begin{array}{l}0.280 * * * \\
(0.063)\end{array}$ \\
\hline ISCED 4 & $\begin{array}{l}0.342 * * * \\
(0.100)\end{array}$ & $\begin{array}{l}0.192 * * * \\
(0.054)\end{array}$ & \\
\hline ISCED 5 & $\begin{array}{l}0.387 * * * \\
(0.098)\end{array}$ & $\begin{array}{l}0.271 * * * \\
(0.044)\end{array}$ & $\begin{array}{l}0.373 * * * \\
(0.062)\end{array}$ \\
\hline English (general) & $\begin{array}{l}0.034 * * \\
(0.017)\end{array}$ & $\begin{array}{l}0.043 * * * \\
(0.015)\end{array}$ & $\begin{array}{l}0.052 * * * \\
(0.017)\end{array}$ \\
\hline French (general) & $\begin{array}{l}0.004 \\
(0.022)\end{array}$ & $\begin{array}{l}-0.023 \\
(0.017)\end{array}$ & $\begin{array}{l}-0.015 \\
(0.021)\end{array}$ \\
\hline Observations & 2443 & 3783 & 5219 \\
\hline Pseudo- $\mathrm{R}^{2}$ & 0.218 & 0.278 & 0.111 \\
\hline
\end{tabular}

Men aged 25-64, Model 1

Marginal effects at the mean estimated for men aged between 25 and 64 years in Germany, Italy, and Spain. Dependent variable: binary variable accounting for the individual employment status. Spanish data do not contain any observation with a level of education equal to ISCED 4

Robust standard errors in brackets $* * * p<0.01 ; * * p<0.05 ; * p<0.1$

the latent model. Marginal effects are computed at the mean (MEM). Hence, we evaluate the effect of foreign language skills on employment for the average man and woman in each country. The results for Model 1 and Model 2 are presented in Tables 5 and 6 for the men's sample, while those for women are shown in Tables 7 and 8. Recall that in all tables the reference levels for the degree of urbanization and education are, respectively, the densely populated area and ISCED 1. As to linguistic variables, the reference group in both models is composed of individuals who do not speak the language examined. 
Table 6 Probit regression

\begin{tabular}{|c|c|c|c|}
\hline Variables & $\begin{array}{l}\text { (1) } \\
\text { Germany }\end{array}$ & $\begin{array}{l}(2) \\
\text { Italy }\end{array}$ & $\begin{array}{l}\text { (3) } \\
\text { Spain }\end{array}$ \\
\hline Age & $\begin{array}{l}0.048 * * * \\
(0.006)\end{array}$ & $\begin{array}{l}0.097 * * * \\
(0.006)\end{array}$ & $\begin{array}{l}0.049 * * * \\
(0.005)\end{array}$ \\
\hline $\mathrm{Age}^{2}$ & $\begin{array}{l}-0.001 * * * \\
(0.000)\end{array}$ & $\begin{array}{l}-0.001 * * * \\
(0.000)\end{array}$ & $\begin{array}{l}-0.001 * * * \\
(0.000)\end{array}$ \\
\hline Married & $\begin{array}{l}0.098 * * * \\
(0.017)\end{array}$ & $\begin{array}{l}0.066^{* * * *} \\
(0.017)\end{array}$ & $\begin{array}{l}0.101 * * * \\
(0.016)\end{array}$ \\
\hline Child & $\begin{array}{l}0.031 \\
(0.020)\end{array}$ & $\begin{array}{l}0.036 * * \\
(0.016)\end{array}$ & $\begin{array}{l}0.062 * * * \\
(0.015)\end{array}$ \\
\hline Intermediate area & $\begin{array}{l}-0.005 \\
(0.016)\end{array}$ & $\begin{array}{l}0.004 \\
(0.014)\end{array}$ & $\begin{array}{l}-0.007 \\
(0.016)\end{array}$ \\
\hline Thinly-populated area & $\begin{array}{l}0.011 \\
(0.019)\end{array}$ & $\begin{array}{l}-0.015 \\
(0.022)\end{array}$ & $\begin{array}{l}0.027 * \\
(0.015)\end{array}$ \\
\hline ISCED 2 & $\begin{array}{l}0.214 * * \\
(0.106)\end{array}$ & $\begin{array}{l}0.109 * * \\
(0.042)\end{array}$ & $\begin{array}{l}0.163 * * * \\
(0.062)\end{array}$ \\
\hline ISCED 3 & $\begin{array}{l}0.317 * * * \\
(0.097)\end{array}$ & $\begin{array}{l}0.229 * * * \\
(0.043)\end{array}$ & $\begin{array}{l}0.281 * * * \\
(0.063)\end{array}$ \\
\hline ISCED 4 & $\begin{array}{l}0.348 * * * \\
(0.100)\end{array}$ & $\begin{array}{l}0.193 * * * \\
(0.054)\end{array}$ & \\
\hline ISCED 5 & $\begin{array}{l}0.381 * * * \\
(0.098)\end{array}$ & $\begin{array}{l}0.270 * * * \\
(0.044)\end{array}$ & $\begin{array}{l}0.374 * * * \\
(0.062)\end{array}$ \\
\hline Sufficient English & $\begin{array}{l}0.030 \\
(0.019)\end{array}$ & $\begin{array}{l}0.043 * * * \\
(0.016)\end{array}$ & $\begin{array}{l}0.068 * * * \\
(0.020)\end{array}$ \\
\hline Good English & $\begin{array}{l}0.038^{*} \\
(0.023)\end{array}$ & $\begin{array}{l}0.035 \\
(0.024)\end{array}$ & $\begin{array}{l}0.022 \\
(0.022)\end{array}$ \\
\hline Proficient English & $\begin{array}{l}0.054 * \\
(0.029)\end{array}$ & $\begin{array}{l}0.059 * \\
(0.034)\end{array}$ & $\begin{array}{l}0.070 * * \\
(0.032)\end{array}$ \\
\hline Sufficient French & $\begin{array}{l}0.002 \\
(0.024)\end{array}$ & $\begin{array}{l}-0.027 \\
(0.020)\end{array}$ & $\begin{array}{l}-0.032 \\
(0.029)\end{array}$ \\
\hline Good French & $\begin{array}{l}0.031 \\
(0.045)\end{array}$ & $\begin{array}{l}-0.024 \\
(0.040)\end{array}$ & $\begin{array}{l}-0.025 \\
(0.037)\end{array}$ \\
\hline Proficient French & $\begin{array}{l}0.029 \\
(0.073)\end{array}$ & $\begin{array}{l}0.023 \\
(0.051)\end{array}$ & $\begin{array}{l}0.047 \\
(0.053)\end{array}$ \\
\hline Observations & 2433 & 3783 & 5215 \\
\hline Pseudo- $\mathrm{R}^{2}$ & 0.223 & 0.278 & 0.112 \\
\hline
\end{tabular}

Men aged 25-64, Model 2

Marginal effects at the mean estimated for men aged between 25 and 64 years in Germany, Italy, and Spain. Dependent variable: binary variable accounting for the individual employment status. Spanish data do not contain any observation with a level of education equal to ISCED 4

Robust standard errors in brackets $* * * p<0.01$; ** $p<0.05 ; * p<0.1$ 
Table 7 Probit regression

\begin{tabular}{|c|c|c|c|}
\hline Variables & $\begin{array}{l}\text { (1) } \\
\text { Germany }\end{array}$ & $\begin{array}{l}(2) \\
\text { Italy }\end{array}$ & $\begin{array}{l}\text { (3) } \\
\text { Spain }\end{array}$ \\
\hline Age & $\begin{array}{l}0.099 * * * \\
(0.008)\end{array}$ & $\begin{array}{l}0.114 * * * \\
(0.008)\end{array}$ & $\begin{array}{l}0.057 * * * \\
(0.006)\end{array}$ \\
\hline $\mathrm{Age}^{2}$ & $\begin{array}{l}-0.001^{* * *} \\
(0.000)\end{array}$ & $\begin{array}{l}-0.001^{* * *} \\
(0.000)\end{array}$ & $\begin{array}{l}-0.001 * * * \\
(0.000)\end{array}$ \\
\hline Married & $\begin{array}{l}-0.032 \\
(0.021)\end{array}$ & $\begin{array}{l}-0.149 * * * \\
(0.021)\end{array}$ & $\begin{array}{l}-0.092 * * * \\
(0.016)\end{array}$ \\
\hline Child & $\begin{array}{l}-0.095 * * * \\
(0.023)\end{array}$ & $\begin{array}{l}0.004 \\
(0.021)\end{array}$ & $\begin{array}{l}-0.030 * \\
(0.016)\end{array}$ \\
\hline Intermediate area & $\begin{array}{l}0.009 \\
(0.020)\end{array}$ & $\begin{array}{l}-0.001 \\
(0.019)\end{array}$ & $\begin{array}{l}-0.008 \\
(0.017)\end{array}$ \\
\hline Thinly-populated area & $\begin{array}{l}0.001 \\
(0.027)\end{array}$ & $\begin{array}{l}-0.006 \\
(0.028)\end{array}$ & $\begin{array}{l}-0.0158 \\
(0.017)\end{array}$ \\
\hline ISCED 2 & $\begin{array}{l}0.183^{* *} \\
(0.084)\end{array}$ & $\begin{array}{l}0.162 * * * \\
(0.034)\end{array}$ & $\begin{array}{l}0.209 * * * \\
(0.039)\end{array}$ \\
\hline ISCED 3 & $\begin{array}{l}0.313 * * * \\
(0078)\end{array}$ & $\begin{array}{l}0.371 * * * \\
(0.035)\end{array}$ & $\begin{array}{l}0.410 * * * \\
(0.041)\end{array}$ \\
\hline ISCED 4 & $\begin{array}{l}0.374 * * * \\
(0.083)\end{array}$ & $\begin{array}{l}0.339 * * * \\
(0.049)\end{array}$ & \\
\hline ISCED 5 & $\begin{array}{l}0.465 * * * \\
(0.078)\end{array}$ & $\begin{array}{l}0.502 * * * \\
(0.036)\end{array}$ & $\begin{array}{l}0.557 * * * \\
(0.040)\end{array}$ \\
\hline English (general) & $\begin{array}{l}0.056^{* *} \\
(0.022)\end{array}$ & $\begin{array}{l}0.057 * * * \\
(0.020)\end{array}$ & $\begin{array}{l}0.011 \\
(0.018)\end{array}$ \\
\hline French (general) & $\begin{array}{l}-0.036 \\
(0.026)\end{array}$ & $\begin{array}{l}-0.026 \\
(0.020)\end{array}$ & $\begin{array}{l}0.003 \\
(0.022)\end{array}$ \\
\hline Observations & 2699 & 3995 & 5685 \\
\hline Pseudo-R ${ }^{2}$ & 0.108 & 0.200 & 0.136 \\
\hline
\end{tabular}

Women aged 25-64, Model 1

Marginal effects at the mean estimated for women aged between 25 and 64 years in Germany, Italy, and Spain. Dependent variable: Binary variable accounting for the individual employment status. Spanish data do not contain any observation with a level of education equal to ISCED 4

Robust standard errors in brackets $* * * p<0.01 ; * * p<0.05 ; * p<0.1$

\subsection{Results for men}

Table 5 presents the results of model 1 for men. The vector of control variables shows the expected signs. Employment status is positively correlated with age and negatively correlated with its square. Being married and having children is positively correlated with the employment status of men in the three countries, which is consistent with the literature on the economic advantages linked to marriage (see Chun and Lee 2001; Pollmann-Schult 2010). The degree of urbanization seems to have no effect, except for Spanish men living in thinly-populated areas, who seem to be more likely to be employed. As expected, education is positively and substantially 
Table 8 Probit regression

\begin{tabular}{|c|c|c|c|}
\hline Variables & $\begin{array}{l}\text { (1) } \\
\text { Germany }\end{array}$ & $\begin{array}{l}(2) \\
\text { Italy }\end{array}$ & $\begin{array}{l}\text { (3) } \\
\text { Spain }\end{array}$ \\
\hline Age & $\begin{array}{l}0.099 * * * \\
(0.008)\end{array}$ & $\begin{array}{l}0.114 * * * \\
(0.008)\end{array}$ & $\begin{array}{l}0.057 * * * \\
(0.006)\end{array}$ \\
\hline $\mathrm{Age}^{2}$ & $\begin{array}{l}-0.001 * * * \\
(0.000)\end{array}$ & $\begin{array}{l}-0.001 * * * \\
(0.000)\end{array}$ & $\begin{array}{l}-0.001 * * * \\
(0.000)\end{array}$ \\
\hline Married & $\begin{array}{l}-0.030 \\
(0.022)\end{array}$ & $\begin{array}{l}-0.149^{* * * *} \\
(0.021)\end{array}$ & $\begin{array}{l}-0.093^{* * * *} \\
(0.016)\end{array}$ \\
\hline Child & $\begin{array}{l}-0.096^{* * *} \\
(0.023)\end{array}$ & $\begin{array}{l}0.004 \\
(0.021)\end{array}$ & $\begin{array}{l}-0.028^{*} \\
(0.016)\end{array}$ \\
\hline Intermediate area & $\begin{array}{l}0.010 \\
(0.020)\end{array}$ & $\begin{array}{l}-0.001 \\
(0.019)\end{array}$ & $\begin{array}{l}-0.008 \\
(0.018)\end{array}$ \\
\hline Thinly-populated area & $\begin{array}{l}0.001 \\
(0.027)\end{array}$ & $\begin{array}{l}-0.005 \\
(0.028)\end{array}$ & $\begin{array}{l}-0.014 \\
(0.017)\end{array}$ \\
\hline ISCED 2 & $\begin{array}{l}0.177 * * \\
(0.085)\end{array}$ & $\begin{array}{l}0.164 * * * \\
(0.034)\end{array}$ & $\begin{array}{l}0.210 * * * \\
(0.039)\end{array}$ \\
\hline ISCED 3 & $\begin{array}{l}0.309 * * * \\
(0.079)\end{array}$ & $\begin{array}{l}0.372 * * * \\
(0.035)\end{array}$ & $\begin{array}{l}0.411 * * * \\
(0.041)\end{array}$ \\
\hline ISCED 4 & $\begin{array}{l}0.372 * * * \\
(0.085)\end{array}$ & $\begin{array}{l}0.340 * * * \\
(0.049)\end{array}$ & \\
\hline ISCED 5 & $\begin{array}{l}0.458 * * * \\
(0.080)\end{array}$ & $\begin{array}{l}0.500 * * * \\
(0.036)\end{array}$ & $\begin{array}{l}0.554 * * * \\
(0.040)\end{array}$ \\
\hline Sufficient English & $\begin{array}{l}0.065 * * * \\
(0.024)\end{array}$ & $\begin{array}{l}0.054 * * \\
(0.021)\end{array}$ & $\begin{array}{l}-0.018 \\
(0.023)\end{array}$ \\
\hline Good English & $\begin{array}{l}0.036 \\
(0.029)\end{array}$ & $\begin{array}{l}0.056^{*} \\
(0.032)\end{array}$ & $\begin{array}{l}0.014 \\
(0.025)\end{array}$ \\
\hline Proficient English & $\begin{array}{l}0.076 * * \\
(0.038)\end{array}$ & $\begin{array}{l}0.076 \\
(0.048)\end{array}$ & $\begin{array}{l}0.121 * * * \\
(0.037)\end{array}$ \\
\hline Sufficient French & $\begin{array}{l}-0.029 \\
(0.031)\end{array}$ & $\begin{array}{l}-0.035 \\
(0.022)\end{array}$ & $\begin{array}{l}0.029 \\
(0.028)\end{array}$ \\
\hline Good French & $\begin{array}{l}0.008 \\
(0.053)\end{array}$ & $\begin{array}{l}0.026 \\
(0.041)\end{array}$ & $\begin{array}{l}-0.004 \\
(0.035)\end{array}$ \\
\hline Proficient French & $\begin{array}{l}-0.080 \\
(0.083)\end{array}$ & $\begin{array}{l}-0.042 \\
(0.062)\end{array}$ & $\begin{array}{l}-0.067 \\
(0.057)\end{array}$ \\
\hline Observations & 2689 & 3995 & 5680 \\
\hline Pseudo- $\mathrm{R}^{2}$ & 0.107 & 0.200 & 0.137 \\
\hline
\end{tabular}

Women aged 25-64, Model 2

Marginal effects at the mean estimated for women aged between 25 and 64 years in Germany, Italy, and Spain. Dependent variable: binary variable accounting for the individual employment status. Spanish data do not contain any observation with a level of education equal to ISCED 4

Robust standard errors in brackets $* * * p<0.01$; ** $p<0.05 ; * p<0.1$ 
rewarded in the labour market, with the probabilities of being employed generally increasing with higher levels of education.

Turning to the linguistic variables, the results for Model 1 show that being able to speak English significantly increases the chances of employment for male individuals in all countries, albeit with differences between them. The marginal effects at the mean for French turn out to be statistically insignificant. Both findings are consistent with those of Araújo et al. (2015) for these countries. Although the authors do not compute the marginal effects, the coefficient of the variable denoting knowledge of English in their latent model is positive and statistically significant, whilst this is not the case for French. Focusing on the differences between the countries, we find that German men speaking English are 3.4\% more likely to be employed than their fellow countrymen who do not. This probability is equal to $4.3 \%$ for Italian men, and to $5.2 \%$ higher in Spain. It is worth noting that the ability to speak English has a limited influence compared with that of the more general level of education. Having an upper secondary education (ISCED 3) enhances the probability of being employed by $31.9 \%$ in Germany, $28 \%$ in Spain and $22.9 \%$ in Italy, that is, from five to more than nine times the magnitude of the respective effect of English skills in each country. At the same time, the conditional correlation between language knowledge and employment is not negligible for men, as it is comparable with the effect of an additional year in all countries.

The relationship between the different levels of language proficiency and employment status of men is presented in Table 6.

The marginal effects of non-linguistic control variables in Model 2 are almost identical to those in Model 1. As regards language skills, the marginal effects for French knowledge are statistically insignificant also when considering specific levels of proficiency. The results presented in Table 6 show that the absence of a conditional correlation between language skills in French and the employment status of men, in the three countries analysed, does not depend on the aggregation of skills' levels. The results for French, nevertheless, must be interpreted with caution because of the relatively low number of individuals in the sample who declare an ability to speak this language at a good, or very good, level.

As expected, a proficient level of skills in English is associated with a greater effect on employment status than sufficient or intermediate levels. There are, however, differences across the countries in this respect. Good and very good skills in English increase the probability of being employed for German men by 3.8 and $5.4 \%$, respectively, while there seems to be no reward for a sufficient level. Italy and Spain show partially different results. In these two countries the conditional correlation between skills in English and respondents' employment status is statistically significant only for sufficient and proficient levels of skills, but not for the intermediate level. The probability of being employed for Italian men with sufficient skills in English is $4.3 \%$ higher than for men who do not know this language, and it increases to $5.8 \%$ if they are proficient in this language. For the Spanish men, the probability of being employed is slightly higher for men with very good language skills in English than for those with just sufficient skills (7 and 6.8\%, respectively). 


\subsection{Results for women}

Table 7 reports the marginal effects for the variable of Model 1 for women. Again, the coefficients of the control variables have the expected sign. As in the case of men, age is positively correlated with employment status. The coefficient of the variable age squared is negative again. In contrast to the situation of men, and consistent with the existing literature in labour economics mentioned above, both marriage and children negatively affect the employment status of women. Interestingly, Italian women appear less likely to be non-employed when married, but not when having children living at home, while the opposite is true for German women. For Spanish women both marriage and having children are negatively correlated with their employment status. The degree of urbanization is correlated with employment, while education is still positively and largely rewarded in the labour market.

Knowledge of English has a positive and relevant effect on the employment status of German and Italian women. This effect is substantially higher than in the case of men: German and Italian women with English skills, respectively, are 5.6 and 5.7\% more likely to be employed than those not speaking it. Instead, knowing English has no significant effect on the employment status of Spanish women. As in the case of men, the conditional correlation between skills in French and employment status is not statistically significant in the three countries studied.

Table 8 presents the results of the regression of Model 2 for women. In this case, too, the estimates of MEM for non-linguistic control variables with Model 2 are very similar to those obtained when using Model 1.

Spanish women who are proficient in English have a 12\% higher probability of being employed than those not speaking it, while sufficient and good skills show no significant effect. This positive effect was "hidden" in Model 1 (in which the conditional correlation between a knowledge of English and employment status is not statistically significant), where differences in the level of linguistic skills are not considered. In the German and Italian labour market the magnitude of the conditional correlation between language skills and employment status varies with the level of proficiency. As in the case of men, for women higher competences are also associated with greater employment opportunities, but not all levels are rewarded. German women are $6.5 \%$ more likely to be employed with a sufficient level of English, and $7.6 \%$ more with a proficient level. For Italian women, the levels of English relevant for an increase in the probability of being employed are "sufficient" and "good", by $5.4 \%$ and 5.6\% respectively. The coefficients for French are not statistically significant in any of the three countries.

\section{Critical discussion and conclusions}

This article examines the relationship between foreign language skills and the employment status of adult native citizens in three EU countries, namely, Germany, Italy, and Spain. The pseudo- $\mathrm{R}^{2}$ indicates that the models work better on the Italian data than the German and Spanish data. To assess whether the results obtained 
depend on the type of effects estimated, we have computed the average marginal effects for the same models presented in Sect. 3. The results point in the same direction as the marginal effects at the mean. Similarly, we tested the robustness of our approach, based on the choice of a non-linear functional form, by estimating two linear probability models that include the same variables specified in the corresponding probit models. In the linear case, too, the estimates show dynamics and magnitudes similar to those of the analysis presented in Sect. 5 .

We tried a specification of the probit models that used additional information in the field of education (e.g. humanities, social sciences, technology), but we found no improvements. A possible strategy to reduce heterogeneity is to use parents' educational level as an instrumental variable instead of the observed level of foreign language knowledge. Nevertheless, this instrumental variable has often been criticised in the language economics literature (see Chiswick and Miller 2015: 242-243 for a detailed discussion), so the problem of disentangling the endogeneity of labour market outcomes and language proficiency has not yet been solved (Chiswick and Miller 1995; Dustmann and van Soest 2001). As a result, a relevant amount of variation in the employment status remains unexplained in our models. We expect that more variation in employment can be explained by differences in the types of job and/or sector of economic activity that are prevalent in the countries considered, e.g. export-oriented manufacturing industries, tourism or agriculture. In other words, part of the variation in the employment status could be explained by the different linguistic requirements in different types of occupation and/or sectors of economic activities. Tables 9 and 10 in the Appendix show the distribution of respondents' language skills in English and French by type of occupation, for men and women respectively. Tables 11 and 12 in the Appendix present the distribution of language skills in the most important economic sectors in terms of the percentage of individuals employed in the total target population. Data show that language skills tend to be more common in certain economic sectors and for certain types of occupation. However, the type of occupation and sector of economic activity are observable only for respondents who are employed and not for the non-employed, which are the two groups of interest to us. The influence of these two variables on employment status cannot be addressed in our models because they examine access to employment at a general level, rather than the specific occupations of jobholders. In order to evaluate the importance of this influence one should be able to control for the selection into labour market participation (this is especially relevant for women). Therefore, a thorough investigation of the relationship between the type of occupation and language skills is a different research question that goes beyond the scope of this article and could be further explored in future analyses.

A methodological issue concerns endogeneity related to unobserved differences among regional labour markets. Foreign language skills may be better rewarded in regions that are closer to the border of neighbouring countries or that are more export-oriented. Indeed, in the three countries examined considerable regional differences exist as regards unemployment rates, for example between the former German Democratic Republic's (GDR) Länder and Bavaria or Baden-Württemberg, between the Italian Mezzogiorno and Lombardy, and between Andalusia and Catalonia in Spain. Further, it is possible that a very good knowledge of French has a 
significant, positive effect on the probability of being employed in border regions, such as Saarland in Germany, or Piedmont in Italy. In this regard, we would expect that regional fixed effects could significantly improve the accuracy of the model. However, we cannot include precise regional fixed effects because no data on the respondents' region of residence is published in the AES. As already shown in Sect. 5, we have instead included the variables as proxies, but with little impact.

Notwithstanding these limitations, this article provides a new contribution to research on the economic value of language skills by presenting additional evidence on the positive relationship between foreign language skills and employment status. Using probit models and data from the Adult Education Survey 2011, we study the conditional correlations between knowledge of English and French as foreign languages and the probability of being employed in the three countries examined. The results reveal that skills in English increase the probability of being employed for men in Germany, Italy, and Spain, respectively, by 3.4, 4.3, and 5.2\%. For women in Germany and Italy, knowledge of English increases the probability of being employed by 5.6 and $5.7 \%$ respectively, whereas in Spain the effect is not significantly different from zero. Higher levels of English skills are associated with a higher probability of being employed. The results for French are not statistically significant in the three countries examined.

It is worth noting for men (and partially for women) the conditional correlation between knowledge of English and employment status is smaller in countries where skills in this language are more common and where the employment level is higher. This could be interpreted as a signal that skills in English tend to be less rewarded in the labour market as they become more widespread among the population, which is consistent with the very fundamental economic concept of scarcity. From this perspective, as English skills spread their value in the labour market will gradually fade (Grin 2001; Gazzola et al. 2018). A second interpretation is that English language skills acquire greater value in labour markets with a lower employment rate because they allow individuals to have a further comparative advantage over competitors. The two interpretations, of course, are not mutually exclusive.

Finally, the results of this article can contribute to informing language policy decisions in education systems. As language skills are acquired mainly through education, establishing a positive relationship between this form of human capital and employment status stresses the importance of language education in Europe, and it provides evidence supporting the views of different employers on this matter. For example, according to the study Employers perceptions of graduate employability carried out on 7036 companies in Europe the majority of employers in the EUexcept in Ireland, the UK, and France-rates "very important" (33\%) or "rather important" (34\%) foreign languages skills when recruiting higher education graduates in their company (European Commission 2010). The lack of sufficient foreign language skills on the labour supply side has been highlighted in various surveys or reports at national level, for example, in Austria (Tritscher-Archan 2008), Denmark, France, Germany, and Sweden (Bel Habib 2011), Italy (Ministry of Labour 2007), and the United Kingdom (Mulkerne and Graham 2011). 
Acknowledgements The authors wish to thank Nannette Swed for her important contribution to an earlier version of this paper, and François Vaillancourt, François Grin, Jacques Melitz, and three anonymous reviewers for their valuable suggestions. We gratefully acknowledge the support from the European Union's Seventh Framework Program (Project "Mobility and Inclusion in a Multilingual Europe," MIME-Grant Agreement 613344), the Research Executive Agency of the European Commission (Project PIEF-GA-2012-327225), the Spanish Ministry of Economy and Competitiveness (ITL Project CSO2015-64247-P).

Open Access This article is distributed under the terms of the Creative Commons Attribution 4.0 International License (http://creativecommons.org/licenses/by/4.0/), which permits unrestricted use, distribution, and reproduction in any medium, provided you give appropriate credit to the original author(s) and the source, provide a link to the Creative Commons license, and indicate if changes were made. The Creative Commons Public Domain Dedication waiver (http://creativecommons.org/publicdomain/zero/1.0/) applies to the data made available in this article, unless otherwise stated.

\section{Appendix}

See Tables 9, 10, 11 and 12. 


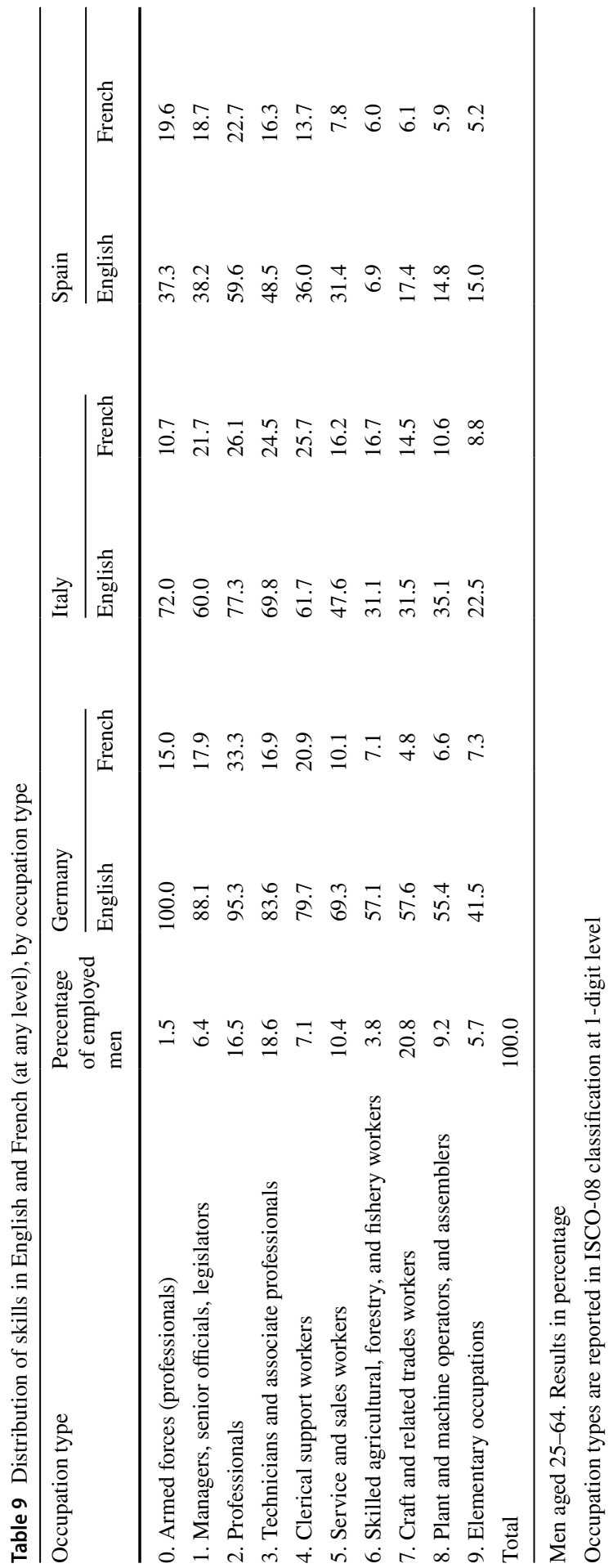




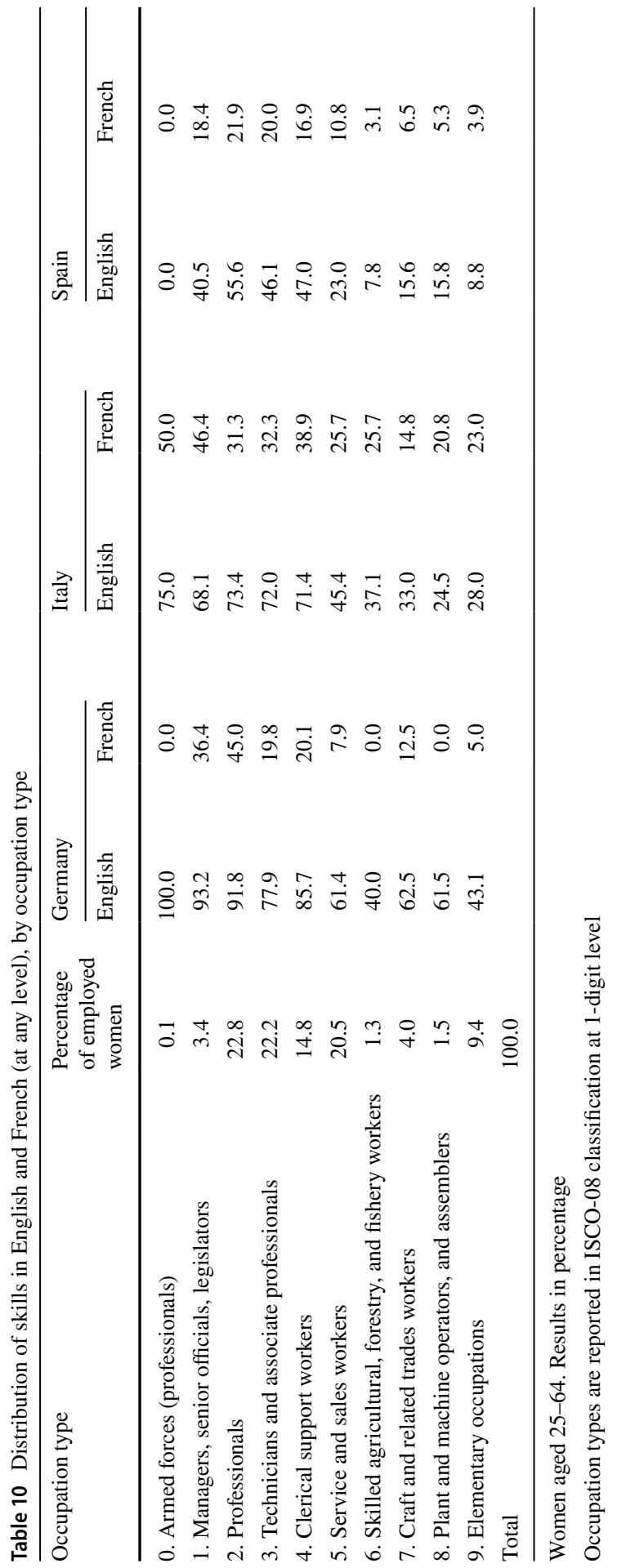




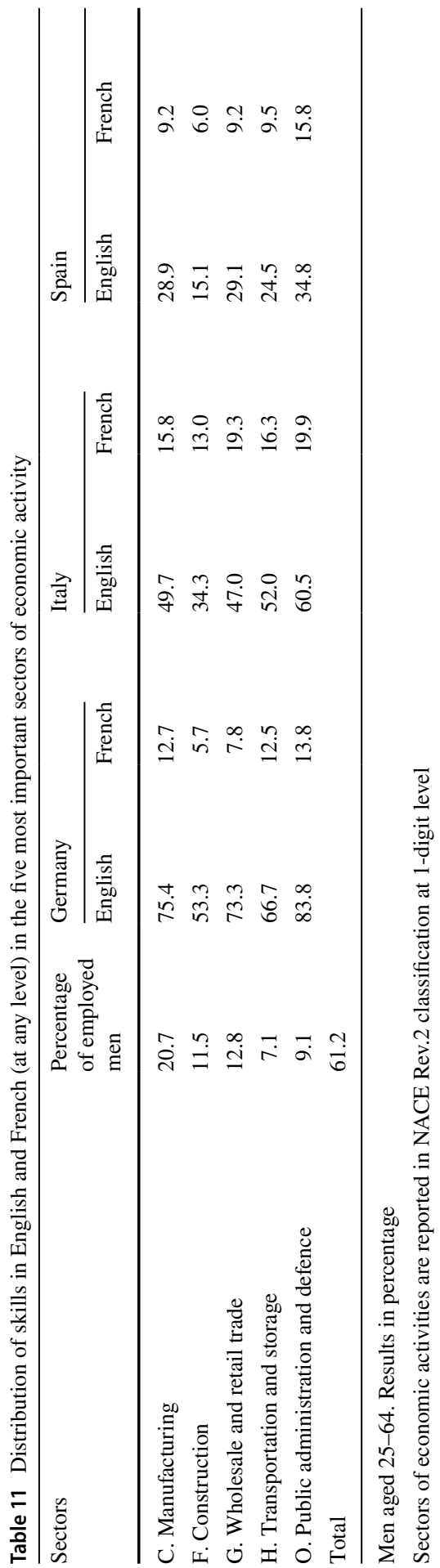




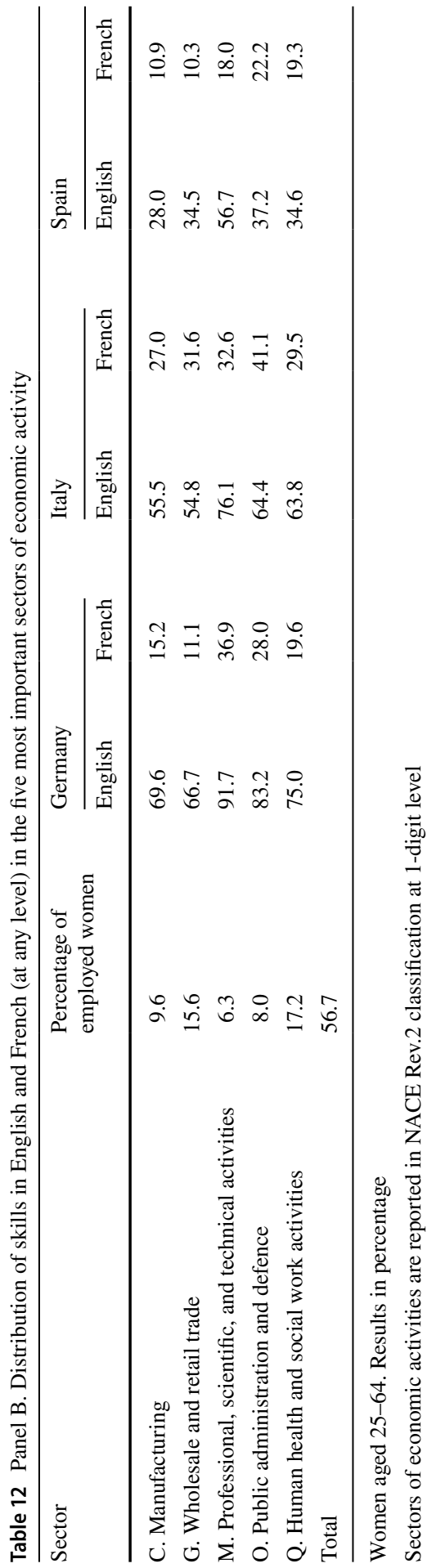




\section{References}

Aldashev A, Gernandt J, Thomsen SL (2009) Language usage, participation, employment and earnings: evidence for foreigners in West Germany with multiple sources of selection. Labour Econ 16:330-341

Araújo L, Dinis da Costa P, Flisi S, Soto Calvo E (2015) Language and employability. European Commission-Joint Research Centre, Luxembourg

Beadle S, Humburg M, Smith R, Vale P (2015) Study on foreign language proficiency and employability. European Commission, Brussels

Bel Habib I (2011) Multilingual skills provide export benefits and better access to new emerging markets. In: Multilingual market communication among Swedish, Danish, German and French small and medium sized enterprises, Sens Public (International Web Journal). University of Montreal, Montreal

Budría S, Colino A, Martínez de Ibarreta C (2019) The impact of host language proficiency on employment outcomes among immigrants in Spain. Empirica. https://doi.org/10.1007/s10663-018-9414-X

Chiswick BR, Miller PW (1995) The endogeneity between language and earnings: international analyses. J Labor Econ 13(2):246-288

Chiswick BR, Miller PW (2007) The economics of language: international analyses. Routledge, New York

Chiswick BR, Miller PW (2015) International migration and the economics of language. In: Chiswick BR, Miller PW (eds) Handbook of the economics of international migration. North Holland, Amsterdam, pp 211-269

Chun H, Lee I (2001) Why do married men earn more: productivity or marriage selection? Econ Inq 39(2):307-317

Cornwell K, Inder B (2008) Language and labour in South Africa. J Afr Econ 17(3):490-525

Di Paolo A, Tansel A (2019) English skills, labour market status and earnings of Turkish women. Empirica. https://doi.org/10.1007/s10663-019-09434-9

Donado A (2017) Foreign languages and their impact on unemployment. Labour 31(3):265-287

Duncan A, Mavisakalyan A (2015) Russian language skills and employment in the Former Soviet Union. Econ Transit 23(3):625-656

Dustman C, Fitzenberge B, Schönber U, Spitz-Oener A (2014) From sick man of Europe to economic superstar: Germany's resurgent economy. J Econ Perspect 28(1):167-188

Dustmann C, Fabbri F (2003) Language proficiency and labour market. Performance of immigrants in the UK. Econ J 113:695-717

Dustmann C, van Soest A (2001) Language fluency and earnings: estimation with misclassified language indicators. Rev Econ Stat 83(4):663-674

European Commission (2003) Promoting language learning and linguistic diversity: an action plan 20042006, COM(2003) 449 final. European Commission, Brussels

European Commission (2005) A new framework strategy for multilingualism, COM(2005) 596 final. European Commission, Brussels

European Commission (2008) Multilingualism: an asset for Europe and a shared commitment, COM(2008) 566 final. European Commission, Brussels

European Commission (2010) Employers' perception of graduate employability, Flash Eurobarometer Series \#304. European Commission, Brussels

European Commission (2012) Language competences for employability, mobility and growth, Accompanying the document. Communication from the Commission. "Rethinking Education: Investing in skills for better socio-economic outcomes". SWD(2012) 372 final. European Commission, Brussels

Fabo B, Beblavy M, Lenaerts K (2017) The importance of foreign language skills in the labour markets of Central and Eastern Europe: assessment based on data from online job portals. Empirica 44(3):487-508

Gazzola M, Grin F, Wickström B-A (2016) A concise bibliography of language economics. In: Gazzola M, Wickström B-A (eds) The economics of language policy. MIT Press, Cambridge, pp 53-92

Gazzola M, Hahm S, Wickström B-A (2018) Sind Fremdsprachenkenntnisse mit dem Einkommen und der Beschäftigung verbunden? Empirische Evidenz aus Deutschland und aus der Welt. In: Brosch C, Fiedler S (eds) Jahrbuch der Gesellschaft für Interlinguistik. Leipziger Universitätsverlag, Leipzig, pp 57-79

Grin F (2001) English as an economic value: facts and fallacies. World Engl 20(1):65-78 
Grin F, Claudio S, Vaillancourt F (2009) Langues étrangères dans l'activité professionnelle, Research Report. University of Geneva, Geneva. https://www.unige.ch/fti/elf/files/7414/5865/9202/LEAPRF-7logos.pdf. Accessed 9 Sept 2019

Grin F, Sfreddo C, Vaillancourt F (2010) The economics of the multilingual workplace. Routledge, London

Isphording I (2015) Language and labor market success. In: Wright J (ed) International encyclopedia of the social \& behavioral sciences, vol 13, 2nd edn. Elsevier, Amsterdam, pp 260-265

Isphording I, Otten S (2014) Linguistic barriers in the destination language acquisition ofimmigrants. J Econ Behav Organ 105:30-50

Jaumotte F (2011) The Spanish labor market in a cross-country perspective, IMF Working Paper. International Monetary Fund, Washington

Krzyżanowski M, Wodak R (2011) Political strategies and language policies: the European Union Lisbon strategy and its implications for the EU's language and multilingualism policy. Lang Policy 10:115-136

Leslie D, Lindley J (2001) The impact of language ability on employment and earnings of Britain's ethnic communities. Economica 68:587-606

Lindemann K, Kogan I (2013) The role of language resources in labour market entry: comparing Estonia and Ukraine. J Ethnic Migr Stud 39(1):105-123

Luoma S (2013) Self-assessment. In: Chapelle CA (ed) The encyclopedia of applied linguistics. WileyBlackwell, New York

Maxwell NL (2010) English language and low-skilled jobs: the structure of employment. Ind Relat 49(3):457-465

McQuaid RW, Lindsay C (2005) The concept of employability. Urban Stud 42(2):197-219

Ministry of Labour (2007) The supply and demand for linguistic education in Italy. Italian Ministry of Labour, Rome. http://bancadati.italialavoro.it/bdds/download?fileName=C_21_Strumento_5936_ documenti_itemName_1_documento.pdf\&uid=5fedb3b9-1b2f-4e57-ae81-b95d3a77740a. Accessed 9 Sept 2019

Mulkerne S, Graham AM (2011) Labour market intelligence on languages and intercultural skills in higher education. University Council of Modern Languages, Southampton

Naticchioni P, Ricci A, Rustichelli E (2010) Far from a skill-biased change: falling education wage premia in Italy. Appl Econ 42(26):3383-3400

Pollmann-Schult M (2010) Marriage and earnings: why do married men earn more than single men? Eur Sociol Rev 27(2):147-163

Rendon S (2007) The Catalan premium: language and employment in Catalonia. J Popul Econ 20:669-686

Ross S (1998) Self-assessment in second language testing: a meta analysis of experimental factors. Lang Test 15(1):1-20

Tritscher-Archan S (ed) (2008) Fremdsprachen für die Wirtschaft. Analysen, Zahlen, Fakten. Institut für Bildungsforschung der Wirtschaft, Vienna

Vaillancourt F (1988) Langue et disparités de statut économique au Québec: 1970 et 1980, Collection Dossiers. Conseil de la langue française, Québec

Yao Y, van Ours JC (2015) Language skills and labor market performance of immigrants in the Netherlands. Labour Econ 25:76-85

Yao Y, van Ours JC (2019) Daily dialect-speaking and wages among native Dutch speakers. Empirica. https://doi.org/10.1007/s10663-018-9420-z

Zhang W, Grenier G (2013) How can language be linked to economics? Lang Probl Lang Plan 37(3):203-226

Zorlu A, Hartog J (2018) The impact of language on socioeconomic integration of immigrants, IZA Discussion Papers Series, No. 11485. Institut zur Zukunft der Arbeit-Institute of Labor Economics, Bonn

Publisher's Note Springer Nature remains neutral with regard to jurisdictional claims in published maps and institutional affiliations. 